\title{
Performance Evaluation of Fly Ash and Red Brick Dust for Recovery of Chromium from Tannery Wastewater by Adsorption Method
}

\author{
Ramsha Rehman ${ }^{1}$, Ammara Khan ${ }^{1}$, Haroon Rashid ${ }^{2}$ and Abdul Nasir
}

${ }^{1}$ M.Sc. (Hons) Agri. Engg Students at University of Agriculture Faisalabad Pakistan

${ }^{2}$ Lecturer, Department of Structures \& Environmental Engineering, University of Agriculture Faisalabad Pakistan

${ }^{3}$ Associate Professor, Department of Structures \& Environmental Engineering, University of Agriculture Faisalabad Pakistan

This is an open access article distributed under the Creative Commons Attribution License, which permits unrestricted use, distribution, and reproduction in any medium, provided the original work is properly cited

\section{ARTICLE DETAILS}

Article history:

Received 26 October 2016 Accepted 10 December 2016 Available online 9 January 2017

Keywords

Red brick dust, Fly ash, Chromium, Adsorption Tannery wastewater

\section{ABSTRACT}

Waste water contains hazardous chemicals released from industries and affects adversely aquatic life as well as deteriorates surface and groundwater quality. The industrial effluent is disposed into drains without treatment thus worsening condition. It alters the living condition of aquatic life and effects the environment adversely. It affects human being some time directly and sometime indirectly. Chromium contamination is a serious problem because of cancer-causing effect of the pollutants and low recovery rate of chromium owing to the existence of organics, such as protein as well as fat. Objective of this study was to determine viability of adsorbents like fly ash and red brick dust for chromium ions recovery from tannery wastewater. Aqueous solutions of $\mathrm{Cr}$ (III) was prepared by dissolving the specific amounts of chromium Sulphate in de ionized water. Concentration of Cr (III) was determined by atomic absorption spectrophotometer. The adsorption of chromium on fly ash as well as red brick dust was determined at different $\mathrm{Cr}$ (III) concentrations, contact time, adsorbent dosage and pH. By comparing results of both adsorbents it was concluded that performance efficiency of both fly ash and red brick dust was good for removal and recovery of chromium. But red brick dust was more effective as compared to fly ash. Because maximum recovery of chromium was observed at $\mathrm{pH} 4$; adsorbent red brick dust; contact time 3hours; and adsorbent dosage $1000 \mathrm{~g}$. Red brick dust declared as good adsorbent for the recovery of chromium from tannery waste water.

\section{Introduction}

Environment is getting flimsy day by day and environmental pollution is one of the undesirable side effects of industrialization, urbanization, population growth and senseless attitude towards the environment Industrial wastes are yielded from divergent processes and the amounts, features of discharged effluent vary from industry to industry depending upon the water consumption and average daily production [1]

Rapid industrialization in developed and developing countries has led to a substantial increase in the generation of industrial wastes. These wastes are a great concern to health scientists all over the world. The presence of these wastes in the environment may affect not only particular species of flora and fauna, but also the structure and function of entire ecosystems [2].In Pakistan industrial estate establishment was started with the introduction of 1st five years plane 1955-1960, which laid emphasis on the establishment of large estates in the country [3].Tannery industry, including leather products, is the 2nd largest export earning sector after textiles in Pakistan. Currently, this sector is contributing around \$ 874 million a year but has the potential to increase volume of exports with the advancement of quality and divergence in different variety of goods, specially clothes and footwear. Currently, Pakistan is amongst the leading countries in the manufacturing of Leather goods. The leather and leather made-ups industry plays a substantial role in the economy of Pakistan and its share in GDP is $4 \%$.

Rapid industrialization in developed and developing countries has led to a substantial increase in the generation of industrial wastes. These wastes are a great concern to health scientists all over the world. The presence of these wastes in the environment may affect not only particular species of flora and fauna, but also the structure and function of entire ecosystems [2].In Pakistan industrial estate establishment was started with the introduction of 1st five years plane 1955-1960, which laid emphasis on the establishment of large estates in the country [3].Tannery industry, including leather products, is the 2nd largest export earning sector after textiles in Pakistan. Currently, this sector is contributing around \$ 874 million a year but has the potential to increase volume of exports with the advancement of quality and divergence in different variety of goods, specially clothes and footwear. Currently, Pakistan is amongst the leading countries in the manufacturing of Leather goods. The leather and leather made-ups industry plays a substantial role in the economy of Pakistan and its share in GDP is $4 \%$.

upon groundwater resources for agricultural and drinking purposes Pakistan, being a creating nation, is likewise confronting serious environmental dangers because of unreliable industrialization and unplanned urbanization [4].

Chromium ( $\mathrm{Cr}$ ) is recorded by the Environmental Protection Agency as one of the 129 need contaminations and one of the 14 most poisonous substantial metals. Presentation to $\mathrm{Cr}$ (III) through inward breath course has been announced as cancer-causing by different offices [5], [6] However, $90 \%$ of tanneries in the world are using chromium salts to produce leather given that it provides better leather flexibility, water resistance and prevents disintegration, properties that are all important for good leather quality [7]. Excessive intake of chromium by human leads to hepatic and renal damage, capillary damage, gastrointestinal irritation and central nervous system irritation [8].

\subsection{Alternative Treatment Techniques for Recovery of Chromium} The pollution of water by overwhelming metals, for example, chromium, copper, cadmium lead and mercury has turned into an expanding issue in the earth and for human wellbeing. Subsequently numerous techniques to decrease lethal toxins have been created. Of late the most widely recognized procedures for expulsion of chromium have been: filtration, reverse osmosis [9], adsorption and concoction responses i.e. lessening and precipitation [10] electro deposition, film frameworks and particle trade forms [11]. Ordinary techniques connected for chromium expulsion have numerous downsides. Henceforth, the adsorption is the most prevalent system to expel overwhelming metals from fluid arrangements [12].

\subsubsection{Adsorption}

Adsorption is the process where molecules are concentrated on the surface of the sorbent. The molecules go from the bulk phase to being adsorbed in the pores in a semi liquid state. The driving force for adsorption is the ratio of the concentration to the solubility of the compound. Adsorption is used widely to remove chromium metals from waters and industrial wastewaters. Adsorption offers significant advantages like low cost, availability, profitability, ease of operation and efficiency, in comparison with conventional methods (such as membrane 
filtration or ion exchange) especially from economic and environmental points of view [13], [14], [15], [16]. In this study two adsorbents are used for removal of chromium by adsorption method:

\section{0bjectives}

Purpose of our study was to determine the feasibility of fly ash and red brick dust as adsorbent for removal and recovery of chromium from tannery wastewater. Second objective was to compare the performance efficiency of fly ash and red brick dust meant for removal of chromium from tannery wastewater.

\section{Material and methods}

3.1 Research Methodology:

Chromium containing aqueous solutions was prepared by using Chromium Sulphate salt. This salt solution was treated against two adsorbents red brick dust and fly ash at different adsorbent dosages (i.e. $250 \mathrm{~g}, 500 \mathrm{~g}, 750 \mathrm{~g}$, and $1000 \mathrm{~g}$ ). The $\mathrm{pH}$ of solutions was maintained at 4 and 9. This research was oriented on the recovery of chromium from aqueous solution so that it could be used for some useful purposes by using some initial treatment.

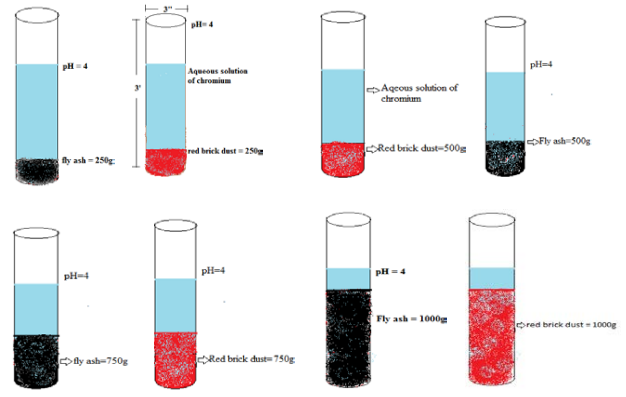

Fig 3.1: pipe arrangement for removal of chromium at $\mathrm{pH}=4$ using red brick dust and fly ash

The same procedure was revised at $\mathrm{pH} 9$.

\subsection{Experimental Methodology:}

In order to assess the performance of each adsorbent and to avoid interference by other elements in waste water, the experiments were conducted with aqueous solution of chromium Sulphate [Cr2 (SO4)3] in distilled water. A stock solution of Chromium ions was prepared by dissolving 3g of chromium Sulphate [Cr2 (SO4)3] in distilled water and solution made up toss $3000 \mathrm{ml}$. The solution $\mathrm{pH}$ was adjusted in the range of 4 and 9 by adding $0.1 \mathrm{~N} \mathrm{HCl}$ and $0.01 \mathrm{~N} \mathrm{NaOH}$ solutions and measured by a $\mathrm{pH}$ meter. Eight samples were prepared for $\mathrm{pH} 4$ and eight for $\mathrm{pH} 9$ before treatment. These solution samples were preserved in refrigerator to avoid any contamination. The prepared solution of different $\mathrm{pH}$ levels was treated against two adsorbents red brick dust and fly ash by using adsorption method. The experiment was repeated for both adsorbents at $\mathrm{pH} 4$ and 9 for different amounts of adsorbent dosages $250 \mathrm{~g} / \mathrm{l}, 500 \mathrm{~g} / \mathrm{l}$, $750 \mathrm{~g} / \mathrm{l}, 1000 \mathrm{~g} / \mathrm{l}$

\begin{tabular}{|c|c|c|c|c|c|}
\hline Adsorbent & Parameters & Before & \multicolumn{3}{|c|}{ After Treatment } \\
\cline { 3 - 6 } & & Treatment & $\mathbf{1 H r}$ & 2Hrs & 3Hrs \\
\hline \multirow{4}{*}{ Red Brick Dust } & $\mathrm{EC}(\mu \mathrm{s} / \mathrm{cm})$ & 1170 & 4290 & 2450 & 2432 \\
\cline { 2 - 6 } & $\mathrm{pH}$ & 4 & 4.6 & 4.8 & 5 \\
\cline { 2 - 6 } & $\mathrm{TDS}(\mathrm{mg} / \mathrm{l})$ & 550 & 2130 & 1220 & 1174 \\
\cline { 2 - 6 } & Chromium $(\mathrm{mg} / \mathrm{l})$ & 2.03 & 1.193 & 1.112 & 1.09 \\
\hline \multirow{3}{*}{ Fly Ash } & $\mathrm{EC}(\mu \mathrm{s} / \mathrm{cm})$ & 1170 & 2400 & 1318 & 1190 \\
\cline { 2 - 6 } & $\mathrm{pH}$ & 4 & 8.3 & 8.1 & 7.8 \\
\cline { 2 - 6 } & $\mathrm{TDS}(\mathrm{mg} / \mathrm{l})$ & 550 & 3751 & 2059 & 1920 \\
\cline { 2 - 6 } & Chromium $(\mathrm{mg} / \mathrm{l})$ & 2.03 & 0.302 & 0.282 & 0.273 \\
\hline
\end{tabular}

Table 2: Results for all Parameters at pH4 \& adsorbent dose 500g

\begin{tabular}{|c|c|c|c|c|c|}
\hline Adsorbent & Parameters & Before & \multicolumn{3}{|c|}{ After Treatment } \\
\cline { 4 - 6 } & & Treatment & $\mathbf{1 H r}$ & $\mathbf{2 H r}$ & 3Hrs \\
\hline \multirow{3}{*}{ Red Brick Dust } & $\mathrm{EC}(\mu \mathrm{S} / \mathrm{cm})$ & 1170 & 2390 & 1598 & 1429 \\
\cline { 4 - 6 } & $\mathrm{pH}$ & 4 & 4.2 & 5.1 & 5.4 \\
\cline { 2 - 6 } & $\mathrm{TDS}(\mathrm{mg} / \mathrm{l})$ & 550 & 2390 & 1598 & 1429 \\
\cline { 2 - 6 } & $\mathrm{Chromium}(\mathrm{mg} / \mathrm{l})$ & 2.03 & 1.523 & 1.23 & 1.124 \\
\hline \multirow{3}{*}{ Fly Ash } & $\mathrm{EC}(\mu \mathrm{S} / \mathrm{cm})$ & 1170 & 2169 & 1950 & 1568 \\
\cline { 2 - 6 } & $\mathrm{pH}$ & 4 & 8.4 & 8.2 & 8.0 \\
\cline { 2 - 6 } & $\mathrm{TDS}(\mathrm{mg} / \mathrm{l})$ & 550 & 2169 & 1950 & 1568 \\
\cline { 2 - 6 } & Chromium $(\mathrm{mg} / \mathrm{l})$ & 2.03 & 0.701 & 0.589 & 0.43 \\
\hline
\end{tabular}

Table 3: Results for all Parameters at pH4 \& adsorbent dose 750g

\begin{tabular}{|c|c|c|c|c|c|}
\hline & & & & & \\
\hline & & Treatment & $1 \mathrm{Hr}$ & $2 \mathrm{Hrs}$ & $3 \mathrm{Hrs}$ \\
\hline Red Brick Dust & $\mathrm{EC}(\mu \mathrm{S} / \mathrm{cm})$ & 1170 & 3770 & 3980 & 4210 \\
\hline & $\mathrm{pH}$ & 4 & 4.6 & 3.6 & 3.8 \\
\hline & TDS (mg/l) & 550 & 1870 & 1990 & 2000 \\
\hline & Chromium (mg/l) & 2.03 & 1.102 & 1.08 & 1.023 \\
\hline Fly Ash & $\mathrm{EC}(\mu \mathrm{S} / \mathrm{cm})$ & 1170 & 2412 & 1403 & 1100 \\
\hline & $\mathrm{pH}$ & 4 & 8.5 & 8.1 & 7.8 \\
\hline & TDS (mg/l) & 550 & 3769 & 2192 & 1879 \\
\hline & Chromium (mg/l) & 2.03 & 0.28 & 0.216 & 0.21 \\
\hline
\end{tabular}

Table 4: Results for all Parameters at pH4 \& adsorbent dose 1000g

\begin{tabular}{|c|c|c|c|c|c|}
\hline & & & & & \\
\cline { 4 - 6 } & & Treatment & $\mathbf{1 H r}$ & 2Hrs & 3Hrs \\
\hline \multirow{3}{*}{ Red Brick Dust } & $\mathrm{EC}(\mu \mathrm{S} / \mathrm{cm})$ & 1170 & 3650 & 3000 & 2980 \\
\cline { 2 - 6 } & $\mathrm{pH}$ & 4 & 3.6 & 3.8 & 4.2 \\
\cline { 2 - 6 } & $\mathrm{TDS}(\mathrm{mg} / \mathrm{l})$ & 550 & 1810 & 1490 & 1133 \\
\cline { 2 - 6 } & Chromium $(\mathrm{mg} / \mathrm{l})$ & 2.03 & 0.301 & 0.289 & 0.202 \\
\hline \multirow{3}{*}{ Fly Ash } & $\mathrm{EC}(\mu \mathrm{S} / \mathrm{cm})$ & 1170 & 4175 & 2565 & 1975 \\
\cline { 2 - 6 } & $\mathrm{pH}$ & 4 & 8.9 & 8.6 & 8.5 \\
\cline { 2 - 6 } & $\mathrm{TDS}(\mathrm{mg} / \mathrm{l})$ & 550 & 6523 & 4008 & 3120 \\
\cline { 2 - 6 } & Chromium $(\mathrm{mg} / \mathrm{l})$ & 2.03 & 0.271 & 0.268 & 0.231 \\
\hline
\end{tabular}

Table 5

\begin{tabular}{|c|c|c|c|c|c|}
\hline Adsorbent & Parameters & Before & \multicolumn{3}{|c|}{ After Treatment } \\
\cline { 4 - 6 } & & Treatment & $\mathbf{1 H r}$ & 2Hrs & 3Hrs \\
\hline \multirow{3}{*}{ Red Brick Dust } & $\mathrm{EC}(\mu \mathrm{S} / \mathrm{cm})$ & 1170 & 3070 & 3100 & 3192 \\
\cline { 2 - 6 } & $\mathrm{pH}$ & 9 & 8.4 & 8.1 & 7.8 \\
\cline { 2 - 6 } & $\mathrm{TDS}(\mathrm{mg} / \mathrm{l})$ & 550 & 1520 & 1540 & 1390 \\
\cline { 2 - 6 } & $\mathrm{Chromium}(\mathrm{mg} / \mathrm{l})$ & 2.03 & 1.923 & 1.851 & 1.412 \\
\hline \multirow{3}{*}{ Fly Ash } & $\mathrm{EC}(\mu \mathrm{S} / \mathrm{cm})$ & 1170 & 2800 & 1647 & 1135 \\
\cline { 2 - 6 } & $\mathrm{pH}$ & 9 & 9.4 & 11.2 & 11.5 \\
\cline { 2 - 6 } & $\mathrm{TDS}(\mathrm{mg} / \mathrm{l})$ & 550 & 3375 & 2574 & 1920 \\
\cline { 2 - 6 } & Chromium $(\mathrm{mg} / \mathrm{l})$ & 2.03 & 0.302 & 0.282 & 0.273 \\
\hline
\end{tabular}

Table 6: Results for all Parameters at pH9 \& adsorbent dose $500 \mathrm{~g}$

\begin{tabular}{|c|c|c|c|c|c|}
\hline Adsorbent & Parameters & Before & \multicolumn{3}{|c|}{ After Treatment } \\
\cline { 3 - 6 } & & Treatment & $\mathbf{1 H r}$ & 2Hrs & 3Hrs \\
\hline \multirow{3}{*}{ Red Brick Dust } & $\mathrm{EC}(\mu \mathrm{S} / \mathrm{cm})$ & 1170 & 3080 & 3150 & 3123 \\
\cline { 2 - 6 } & $\mathrm{pH}$ & 9 & 8.4 & 8.2 & 8.5 \\
\cline { 2 - 6 } & $\mathrm{TDS}(\mathrm{mg} / \mathrm{l})$ & 550 & 1530 & 1550 & 1477 \\
\cline { 2 - 6 } & Chromium $(\mathrm{mg} / \mathrm{l})$ & 2.03 & 1.19 & 1.08 & 1.09 \\
\hline \multirow{3}{*}{ Fly Ash } & $\mathrm{EC}(\mu \mathrm{S} / \mathrm{cm})$ & 1170 & 2975 & 1763 & 1711 \\
\cline { 2 - 6 } & $\mathrm{pH}$ & 9 & 9.4 & 8.6 & 8.2 \\
\cline { 2 - 6 } & $\mathrm{TDS}(\mathrm{mg} / \mathrm{l})$ & 550 & 3810 & 2490 & 1866 \\
\cline { 2 - 6 } & Chromium $(\mathrm{mg} / \mathrm{l})$ & 2.03 & 0.321 & 0.298 & 0.292 \\
\hline
\end{tabular}

Table 7: Results for all Parameters at pH9 \& adsorbent dose 750g

\begin{tabular}{|c|c|c|c|c|c|}
\hline Adsorbent & Parameters & Before & \multicolumn{3}{|c|}{ After Treatment } \\
\cline { 3 - 6 } & & Treatment & $\mathbf{1 H r}$ & $\mathbf{2 H r s}$ & 3Hrs \\
\hline \multirow{3}{*}{ Red Brick Dust } & $\mathrm{EC}(\mu \mathrm{S} / \mathrm{cm})$ & 1170 & 4000 & 3280 & 3219 \\
\cline { 2 - 6 } & $\mathrm{pH}$ & 9 & 5.6 & 4.8 & 4.6 \\
\cline { 2 - 6 } & $\mathrm{TDS}(\mathrm{mg} / \mathrm{l})$ & 550 & 3950 & 3390 & 3219 \\
\cline { 2 - 6 } & $\mathrm{Chromium}(\mathrm{mg} / \mathrm{l})$ & 2.03 & 1.39 & 1.273 & 1.212 \\
\hline \multirow{3}{*}{ Fly Ash } & $\mathrm{EC}(\mu \mathrm{S} / \mathrm{cm})$ & 1170 & 2750 & 1630 & 1355 \\
\cline { 2 - 6 } & $\mathrm{pH}$ & 9 & 10.3 & 9.7 & 9.2 \\
\cline { 2 - 6 } & $\mathrm{TDS}(\mathrm{mg} / \mathrm{l})$ & 550 & 4210 & 2490 & 2100 \\
\cline { 2 - 6 } & Chromium $(\mathrm{mg} / \mathrm{l})$ & 2.03 & 1.231 & 1.22 & 1.20 \\
\hline
\end{tabular}

Table 8: Results for all Parameters at pH9 \& adsorbent dose $1000 \mathrm{~g}$

\begin{tabular}{|c|c|c|c|c|c|}
\hline Adsorbent & Parameters & Before & \multicolumn{3}{|c|}{ After Treatment } \\
\cline { 3 - 6 } & & Treatment & $\mathbf{1 H r}$ & $\mathbf{2 H r s}$ & 3Hrs \\
\hline \multirow{3}{*}{$\begin{array}{c}\text { Red Brick } \\
\text { Dust }\end{array}$} & $\mathrm{EC}(\mu \mathrm{S} / \mathrm{cm})$ & 1170 & 3101 & 2044 & 2038 \\
\cline { 2 - 6 } & $\mathrm{pH}$ & 9 & 4.9 & 4.2 & 3.9 \\
\cline { 2 - 6 } & $\mathrm{TDS}(\mathrm{mg} / \mathrm{l})$ & 550 & 1952 & 1674 & 995 \\
\cline { 2 - 6 } & Chromium $(\mathrm{mg} / \mathrm{l})$ & 2.03 & 1.152 & 1.322 & 1.334 \\
\hline \multirow{3}{*}{ Fly Ash } & $\mathrm{EC}(\mu \mathrm{S} / \mathrm{cm})$ & 1170 & 3001 & 1930 & 1874 \\
\cline { 2 - 6 } & $\mathrm{pH}$ & 9 & 9.8 & 11.1 & \\
\cline { 2 - 6 } & $\mathrm{TDS}(\mathrm{mg} / \mathrm{l})$ & 550 & 3910 & 2490 & 2122 \\
\cline { 2 - 6 } & Chromium $(\mathrm{mg} / \mathrm{l})$ & 2.03 & 1.091 & 0.979 & 0.921 \\
\hline
\end{tabular}

4.2. Graphical presentation of all parameters after treatment: Effect on EC:

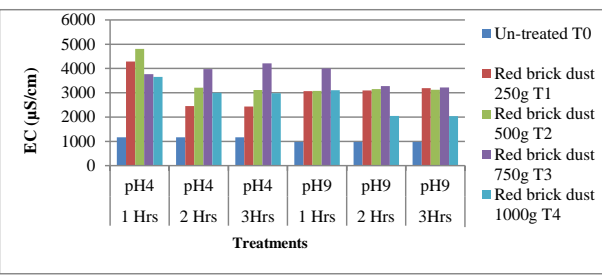

Fig 1: EC values of Red Brick Dust 


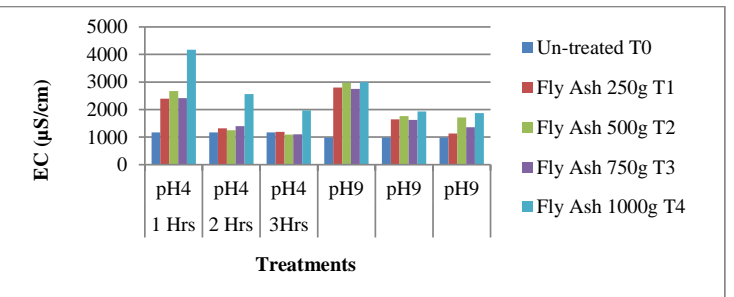

Fig 2: EC values of Fly Ash
Effect on TDS:

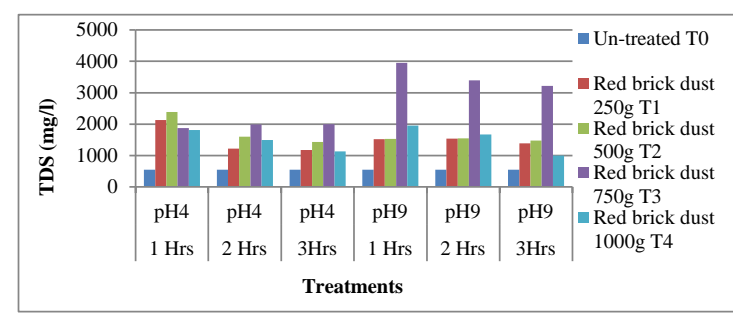

Fig 3: TDS values of Red Brick Dust

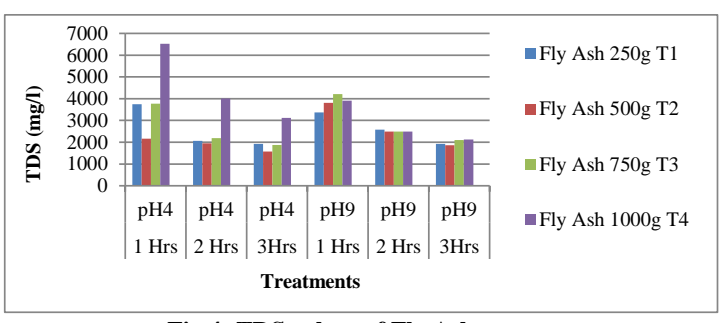

Fig 4: TDS values of Fly Ash

\section{Effect of $\mathrm{pH}$ :}

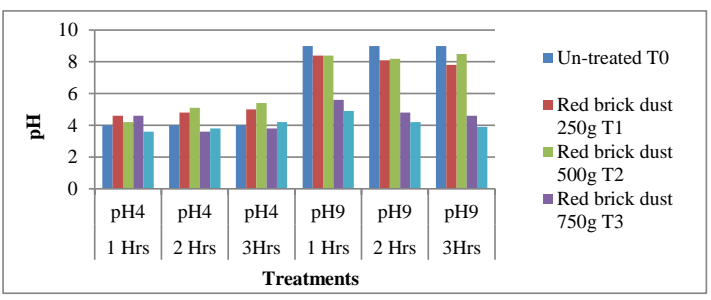

Fig 5: pH values of Red Brick Dust

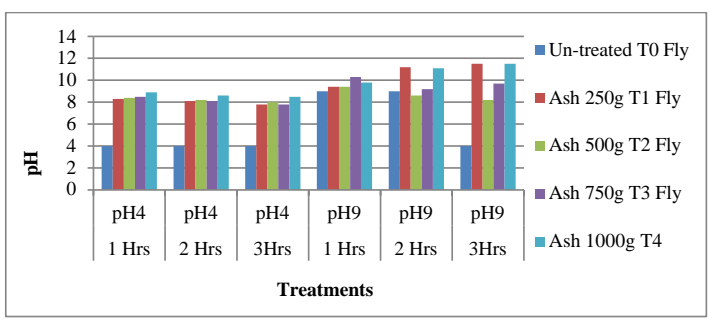

Fig 6: pH values of Fly Ash

Effect on Chromium Removal:

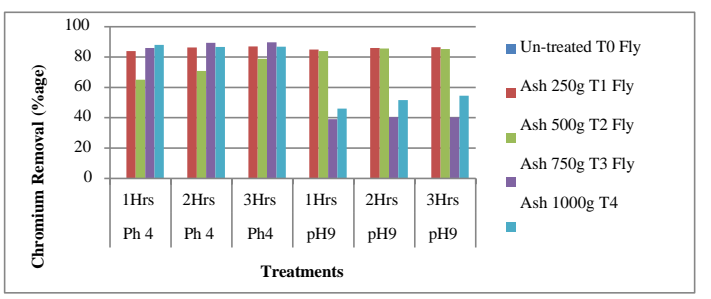

Fig 7: Chromium values of Fly Ash

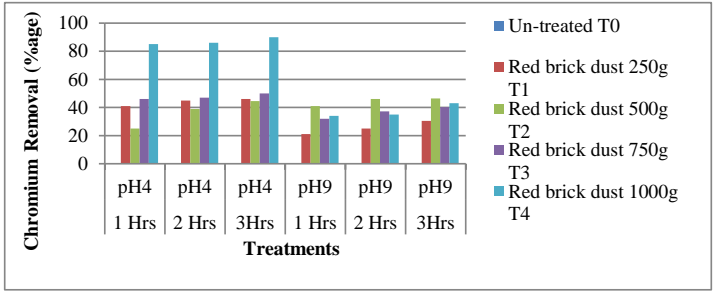

Fig 8: Chromium values of Red Brick Dust

\section{Discussion}

In Fig 1Experimental results showed that the red brick dust application for $\mathrm{pH} 4$ and $\mathrm{pH} 9$ indicated high results as compare to control treatment. The T4 presented lowest EC results $2980 \mu \mathrm{S} / \mathrm{cm}$ and $2038 \mu \mathrm{S} / \mathrm{cm}$ at 3 hour interval for $\mathrm{pH} 4$ and $\mathrm{pH} 9$ respectively. Fly ash exhibited the same trend as displayed the brick dust and results of treatments increased form the control treatment. For pH4 T2 showed the best results after 3 hours interval with EC value $1094 \mu \mathrm{S} / \mathrm{cm}$. T1 showed the lowest results for $\mathrm{pH} 9$ after 3 hours interval with EC value $1135 \mu \mathrm{S} / \mathrm{cm}$ as shown in fig 2 .

In Fig 3 results revealed that as the red brick dust application for $\mathrm{pH} 4$ and pH9 have shown high results as compare to control treatment. Treatment T3 showed exceptional behavior as its values were increased with increase in retention time. $\mathrm{T}_{1}$ and $\mathrm{T}_{4}$ exposed lowest values of TDS results $1174 \mathrm{mg} / \mathrm{l}$ and $1133 \mathrm{mg} / \mathrm{l}$ at 3 hour interval for $\mathrm{pH} 4$ as well as $1390 \mathrm{mg} / \mathrm{l}$ and $995 \mathrm{mg} / \mathrm{l}$ for $\mathrm{pH} 9$ respectively. Fly ash presented the same trend as in case of brick dust and results of treatments increased from the control treatment. For $\mathrm{pH}_{4} \mathrm{~T}_{2}$ and $\mathrm{T}_{3}$ showed the best results after 3 hours interval with TDS value $1568 \mathrm{mg} / \mathrm{l}$ and $1879 \mathrm{mg} / \mathrm{l}$. For pH9 T2 and T1 showed the best results after 3 hours interval with TDS value $1920 \mathrm{mg} / \mathrm{l}$ and $1866 \mathrm{mg} / \mathrm{l} . \mathrm{T}_{4}$ and $\mathrm{T}_{3}$ showed the highest results at $\mathrm{pH} 4$ and $\mathrm{pH} 9$ as shown in fig 4 .

In fig 5 results revealed that as the red brick dust application for $\mathrm{pH} 4$ indicated with the increase of retention time $\mathrm{pH}$ of the solutions was turning to basic nature. At $\mathrm{pH} 9$, after treatment $\mathrm{pH}$ values were going acidic in nature. For $\mathrm{pH} 4$ the $\mathrm{T}_{2}$ have shown maximum $\mathrm{pH}$ value result 5.4 at time interval of 3 hours. For pH9 T4 showed lowest $\mathrm{pH}$ value as 4.2. Fly ash exposed the maximum values of $\mathrm{pH}$ after treatment. For $\mathrm{pH}_{4} \mathrm{~T}_{4}$ showed the peak value of $\mathrm{pH} 8.9$ after 1 hour interval which is basic in nature. For $\mathrm{pH} 9 \mathrm{~T}_{2}$ showed the lowest value of $\mathrm{pH}$ as 8.2 as shown in fig 6.Other three treatments $\mathrm{T}_{1}, \mathrm{~T}_{3}, \mathrm{~T}_{4}$ indicated increased values of $\mathrm{pH}$ after treatment as $11.5,9.7$ and 11.5 respectively.

Fly ash presented the same trend as the brick dust and results of treatments decreased from the control treatment. For $\mathrm{pH}_{4} \mathrm{~T}_{3}$ showed the best results for chromium removal as $0.21 \mathrm{mg} / \mathrm{l}$ after 2 hours interval as shown in fig $7 . \mathrm{T}_{3}$ exposed the best results for $\mathrm{pH} 9$ after 3 hours interval with Chromium contents $0.273 \mathrm{mg} / \mathrm{l}$. Experimental results described that as the red brick dust application for $\mathrm{pH} 4$ showed better results as compare to control treatment. Same behavior was found in $\mathrm{pH} 9$. The T4explained best Chromium removal $0.202 \mathrm{mg} / \mathrm{l}$ at 3 hour interval for pH4.Similarly $\mathrm{T}_{2}$ exhibited best removal of chromium as $1.092 \mathrm{mg} / \mathrm{l}$ at 2hour interval time as shown in fig 8.

\section{Conclusion and Recommendations}

Chromium was efficiently reduced by red brick dust treatment as compared to Fly ash. Best chromium recovery was achieved at $\mathrm{pH} 4$, contact time of 3hours; adsorbent dosage $1000 \mathrm{~g}$ and results obtained are very close to NEQS. TDS values of the chromium solutions were also going to increase after treatment with red brick dust and fly ash. Most important thing is that the $\mathrm{pH}$ of solutions exhibited diversified trend after treatment of the chromium solutions. Acidic nature of solution changed into basic nature and vice versa after treating them with both adsorbents. Conclusively, recovery of chromium was achieved by using red brick dust. It means red brick dust is the cheapest material which could be used on source for treatment of tannery waste water by conserving soil and water resources. Further studies are to be continued for increasing the adsorption potential of the red brick dust by treating it with other chemicals or acids. Combined treatment plant are highly suggested under this study, so that the economical load equally distributed on industries and the proper treatment will be performed to save our ground water sources, agriculture land and aquatic life also. 


\section{Acknowledgement}

The authors would like to thank the University of Agriculture

Faisalabad (UAF) and, water and sanitation authority (WASA) for supporting this research through funding and laboratory services.

\section{References}

[1] Shen, T. T. 1999.Impacts of Chromium from Tannery Effluent and Evaluation of Alternative Treatment Options. Journal of Environmental Protection .pp. 40.

[2. Fent, K. 2003. Eco toxicological problems associated with contaminated sites. Toxicol Lett. 140-141:353-365.

[3] Nasrullah, N. R., Bibi, H., Iqbal, M and Durrani, M. I. 2006. Pollution load in industrial effluent and ground water of Gadoon Amazai industrial estate (Gaie) Swabi, NWFP. Journal of Agricultural and Biological Science. 1(3). 18-24.

[4] Tariq, S. R., M.H. Shah., N. Shaheen., A. Khalique., S. Manzoor and M. Jaffar. 2005. Multivariate analysis of selected metals in tannery effluents and related soil, J. Hazad. Mat. 122:17-22.

[5] IARC 1990. Monographs on the evaluation of carcinogenic risks to humans: Chromium, Nickel and welding. International Agency for Research on Cancer, Lyons. 38: 49-256.

[6] US EPA 1998. Toxicological review of hexavalent chromium. Integrated Risk Information System. Office of Health and Environmental Assessment, US Environmental Protection Agency, Cincinnati, $\mathrm{OH}$.

[7] Lebrun, R., Ortega, L. M., Noel, I. M and Hausler, R. 2004. Application of nanofiltration in the recovery of chromium (III) from tannery effluents. Separation and Purification Technology. 44:45-52.

[8] Raju, K. S and Naidu, S. V. 2013. A review on removal of heavy metal ions from wastewater by rice husk as an adsorbent. Journal of Chem Bio Phy Sci. 3(2):602-606.

[9] Das, C., Patel, P., De, S and DasGupta, S., 2006. Treatment of tanning effluent using nanofiltration followed by reverse osmosis, Separation and Purification Technology. 50:291-299.

[10] Hagendorfer, $\mathrm{H}$ and Goessler, W. 2008. Separation of chromium (III) and chromium (VI) by ion chromatography and an inductively coupled plasma mass spectrometer as element-selective detector, Talanta. 30:656-661.

[11] Xing, Y., Chen, X and Wang, D. 2007. Electrically regenerated ion exchange for removal and recovery of $\operatorname{Cr}(\mathrm{VI})$ from wastewater. Environmental Science and Technology. 41: 14391443.

[12] Karthikeyan, T., Rajgopal, S and Miranda, L.M. 2005. Chromium (VI) adsorption from aqueous solution by Hevea Brasilinesis sawdust activated carbon. Journal of Hazardous Materials. 124:192-199.

[13] Hashem, A., Akasha, R. A., Ghith, A and Hussein, D. A. 2007. Adsorbent based on agricultural wastes for heavy metal and dye removal. Energy Edu. Sci. Technol. 19:69 -86.

[14] Ravikumar, K., Deebika, B and Balu, K. 2005. Decolourization of aqueous dye solutions by a novel adsorbent: Application of statistical designs and surface plots for the optimization and regression analysis. Journal of Hazardous Materials. 122(1-2):75-83.

[15] Allen, S. J., Gan, Q., Matthews, R and Johnson, P. A. 2005. Kinetic modeling of the adsorption of basic dyes by kudzu. Journal of Colloid and Interface Science. 286(1):101-109.

[16] Mittal, A., Krishnan, L and Gupta, V. K. 2005. Removal and recovery of malachite green from wastewater using an agricultural waste material. Purif. Technol. 43(2):125-133. 